\title{
RIGHTCANIA AND KVACEKISPERMUM: EARLY CRETACEOUS SEEDS FROM EASTERN NORTH AMERICA AND PORTUGAL PROVIDE FURTHER EVIDENCE OF THE EARLY CHLORANTHOID DIVERSIFICATION
}

\author{
ELSE MARIE FRIIS ${ }^{1, *}$, PETER R. CRANE ${ }^{2,3}$, KAJ RAUNSGAARD PEDERSEN ${ }^{4}$ \\ 1 Department of Palaeobiology, Swedish Museum of Natural History, Box 50007, SE-104 05 Stockholm, Sweden; \\ e-mail: else.marie.friis@nrm.se. \\ ${ }^{2}$ Oak Spring Garden Foundation, 1776 Loughborough Lane, Upperville, Virginia 20184 USA. \\ ${ }^{3}$ School of Forestry and Environmental Studies, Yale University, New Haven, Connecticut 06511 USA \\ ${ }^{4}$ Department of Geoscience, University of Aarhus, Høegh-Guldbergs Gade 2, DK-8000 Aarhus C Denmark. \\ ${ }^{*}$ corresponding author
}

Friis, E. M., Crane, P. R., Pedersen, K. R. (2018): Rightcania and Kvacekispermum: Early Cretaceous seeds from eastern North America and Portugal provide further evidence of the early chloranthoid diversification. - Fossil Imprint, 74(1-2): 65-76, Praha. ISSN 2533-4050 (print), ISSN 2533-4069 (on-line).

\begin{abstract}
Abundant flowers, fruits, seeds and stamens that are closely related to extant Chloranthaceae have been reported from the Early Cretaceous floras of Portugal. Among these are small berries with endotestal seeds assigned to the extinct genera Canrightia and Canrightiopsis. Here we describe two new genera, each including a single species, based on fossil fruits and seeds from the Early Cretaceous of eastern North America and Portugal. Both genera have pendent, orthotropous, bitegmic and endotestal ovules/seeds, in which the endotesta consists of a layer of cubic to palisade-shaped crystal cells with endoreticulate fibrous infillings, a combination of features that also characterize Canrightia and Canrightiopsis and that among extant angiosperms are known only for members of the Chloranthaceae. Rightcania kvacekii gen. et sp. nov. from the early to middle Albian Puddledock mesofossil flora of Virginia, USA, is the first representative in the Early Cretaceous floras of North America of a chloranthaceous fossil related to Canrightia and Canrightiopsis. It has three- to five-seeded fruits very similar to fruits and seeds of Canrightia, also with a pronounced tegmen that probably functioned as a nutritive tissue for the developing embryo. Fruits and seeds of Rightcania are larger than those of Canrightia, and also differ in details of the seed coat. Kvacekispermum rugosum gen. et sp. nov. is rare in the late Aptian to early Albian Portuguese mesofossil flora from Vale de Água. It differs from Canrightiopsis in the coarsely rugulate outer surface of the endotesta and its larger size, but is closely similar in the general structure of seed coat and nutritive tissue. Together, Rightcania and Kvacekispermum provide further evidence of the early diversity achieved by chloranthoid angiosperms before the end of the Early Cretaceous.
\end{abstract}

Key words: Canrightia, Canrightiopsis, Chloranthaceae, fossil seeds, mesofossil floras, synchrotron radiation X-ray tomographic microscopy (SRXTM)

Received: December 19, 2017 | Accepted: March 3, 2018 | Issued: August 31, 2018

\section{Introduction}

Early Cretaceous mesofossil floras from eastern North America and Portugal have yielded an extraordinary diversity of small angiosperm fruits and seeds in fossil assemblages that also include angiosperm flowers and other plant fragments (e.g. Friis et al. 2011). Most of these seeds have an exotestal seed coat in which the mechanical protective layer is in the outer layer of the outer integument. The features of these seeds indicate a relationship to extant Austrobaileyales and Nymphaeales, although in most cases the fossils cannot be placed in any extant family or order (Friis et al. 1999, 2011, 2018a; see also Friis et al. 2018b this issue). A smaller proportion of the Early Cretaceous seeds are endotestal, in which the mechanical protective layer is in the inner part of the outer integument and among these are taxa related to Magnoliales (Friis, Crane and Pedersen, work in progress) and especially extant Chloranthaceae (Friis and Pedersen 2011, Friis et al. 2015). Extant Chloranthaceae are clearly relictual with only four surviving genera (Ascarina J.R.FORSTER et G.FORSTER, Chloranthus O.Swartz, Hedyosmum O.SwARTz, and Sarcandra GARDNER), which show a scattered pantropical distribution that includes occurrences in Asia, the Pacific Islands and Central and South America (Todzia 1993). 
Today the family comprises ca. 75 extant species, many of which are putatively of relatively recent origin (e.g. Zhang and Renner 2003), but the extensive Early Cretaceous record of unequivocal chloranthoid flowers, fruits, seeds, stamens and pollen documents that the group had attained considerable diversity much earlier and an almost global distribution by the Albian (Early Cretaceous). Especially significant is the wide distribution of the characteristic pollen of Asteropollis Hedlund et NorRis (Hedlund and Norris 1968), which has a tectum and aperture configuration almost indistinguishable from pollen of extant Hedyosmum (Walker and Walker 1984). Early Cretaceous records of Asteropollis extend from Antarctica to Greenland and from America and Europe to eastern Asia (for literature see Martínez et al. 2013). Dispersed pollen of Clavatipollenites COUPER is also important for interpreting the early evolutionary history of chloranthoids and includes species that are closely similar to pollen of extant Ascarina (Couper 1960, Walker and Walker 1984, Archangelsky and Taylor 1993). However, since there is a considerable diversity among dispersed pollen grains assigned to Clavatipollenites they may not all be related to Chloranthaceae. More detailed analysis using scanning electron microscopy is needed if Clavatipollenites is to be used to indicate the past distribution of chloranthoids (Hughes 1994, Friis et al. 2011).

Interpreting the early fossil history of chloranthoids has been greatly facilitated by the discovery of a variety of chloranthoid mesofossils, including floral structures, fruits, seeds and stamens (Crane et al. 1989, Herendeen et al. 1993, Crane et al. 1994, Eklund et al. 1997, Friis et al. 2011, Hartkopf-Fröder et al. 2011). While much less abundant than dispersed pollen grains, such mesofossils are common in Early Cretaceous sediments from Portugal, and because they are relatively rich in systematically informative characters, they are especially valuable for understanding the early phases of chloranthoid evolution. Among these early chloranthoids are Hedyosmum-like flowers, fruits and staminate structures and several undescribed taxa, as well as floral structures, fruits and seeds assigned to species of the extinct genera Canrightia E.M.Friss et K.R.Pedersen and Canrightiopsis E.M.Fris, G.W.Grimm, M.M.Mendes et K.R.Pedersen (Friis et al. 1997, 2011, Friis and Pedersen 2011, Friis et al. 2015). Canrightia and Canrightiopsis are closely similar to extant Chloranthus, Sarcandra and Ascarina in having pendent, orthotropous, bitegmic and endotestal ovules/seeds, in which the outer integument (testa) and the inner integument (tegmen) are distinct. The mechanical layer is in the inner part of testa (endotesta) and consists of one layer of cubic to palisade-shaped crystal cells with endoreticulate fibrous infillings. Canrightia and Canrightiopsis differ from the extant genera of Chloranthaceae in several features and their discovery has been particularly important for unravelling the evolution of the unique dorsally displaced androecium of extant Sarcandra and Chloranthus (Friis et al. 2015).

Here we describe two new extinct chloranthoids, Rightcania kvacekii gen. et sp. nov. from the Puddledock flora of Virginia, USA, and Kvacekispermum rugosum gen. et sp. nov. from the Vale de Água locality, Portugal. Both genera have features of ovule organization and seed coat comparable to Canrightia, Canrightiopsis and related extant Chloranthaceae. Rightcania kvacekii is particularly similar to Canrightia in having more than one ovule/seed in the fruit, while Kvacekispermum is closely similar to seeds of Canrightiopsis. Rightcania kvacekii from the Puddledock flora is the first record of a member of the CanrightiaCanrightiopsis complex from North America, and together the two new genera provide further evidence of the extensive extinct diversity among early chloranthoid angiosperms that were widespread during the Early Cretaceous at a very early stage of angiosperm evolution.

\section{Material and methods}

The fossil specimens were recovered from Early Cretaceous sediments from the Puddledock and Vale de Água localities. Sediments at the Puddledock locality are of early to middle Albian age. They outcrop in a large clay pit, the former Tarmac Lone Star Industries (now Vulcan Materials Co.) sand and gravel pit, located south of Richmond and east of the Appomattox River in Prince George County, Virginia, USA $\left(37^{\circ} 15^{\prime} 52^{\prime \prime} \mathrm{N}, 77^{\circ} 22^{\prime} 10^{\prime \prime} \mathrm{W}\right)$. Sediments at the Vale de Água locality are of late Aptian to early Albian age. They outcrop in a huge clay pit complex near the small villages of Vale de Água and Juncal, southwest of Batalha in the Lusitanian Basin (39 $37^{\prime} 15^{\prime \prime} \mathrm{N}, 08^{\circ} 51^{\prime} 30^{\prime \prime} \mathrm{W}$ ), western Portugal. Further information on the geological context and age of the plant fossils from the two localities is given in Friis et al. (2011). For comparison with the new material described here we also illustrate seeds of Canrightia (Friis and Pedersen 2011) and Canrightiopsis from the Early Cretaceous of Portugal (Friis et al. 2015).

The fossils were extracted from the sediments and cleaned for further analysis following standard procedures (e.g. Friis et al. 2009, 2018b this issue). They were studied using attenuation-based synchrotron radiation X-ray tomographic microscopy (SRXTM) at the TOMCAT beamline of the Swiss Light Source of the Paul Scherrer Institute, Villigen, Switzerland (Stampanoni et al. 2006, Friis et al. 2014). For SRXTM analyses specimens were mounted on brass stubs using nail polish and analyses were carried out at $10 \mathrm{keV}$ with a sCMOS detector and a $20 \mu \mathrm{m}$ thick LAG:Ce scintillator screen using a 10× objective (PP56562, PP56593, PP56599, S171512, S174004, S174039, S174159, $\mathrm{S} 174951, \mathrm{~S} 174952$; isotopic pixel size $0.65 \mu \mathrm{m})$ or $20 \times$ objective (S174100, S174004; isotopic pixel size 0.325 $\mu \mathrm{m})$ over $180^{\circ}$. Examination of specimen PP56562 used horizontal two-fold expansion with projections over $360^{\circ}$ (for details see Friis et al. 2014).

The fossil seeds are housed in the palaeobotanical collections of the Field Museum, Chicago (PP numbers) and in the palaeobotanical collections of the Swedish Museum of Natural History, Stockholm (S numbers), where also raw data are stored.

New names of fossil plants are being registered in the Plant Fossil Names Registry, which is hosted and operated by the National Museum, Prague for the International Organisation of Palaeobotany (IOP), each with a unique registry number. 

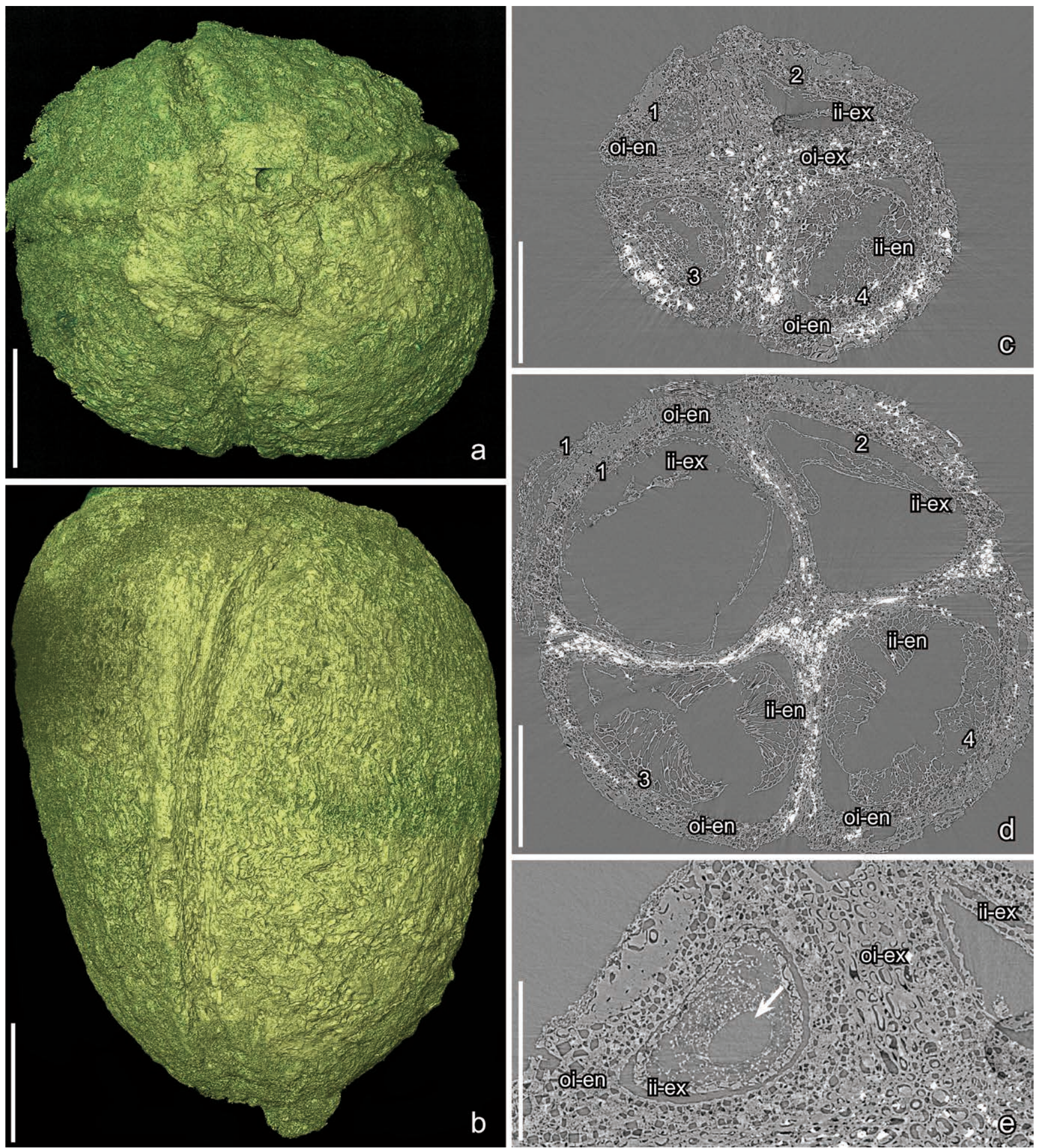

b

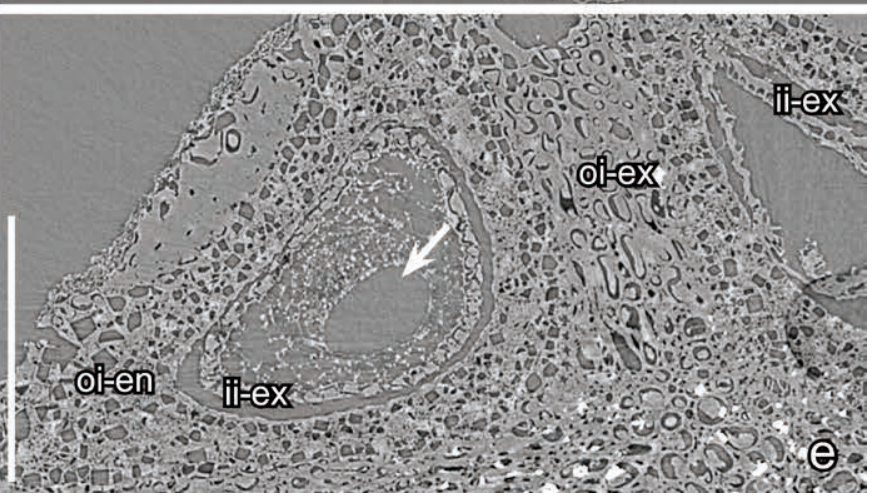

Text-fig. 1. Synchrotron radiation X-ray tomographic microscopy (SRXTM) images of Rightcania kvacekii gen. et sp. nov. from the Early Cretaceous Puddledock locality, Virginia, USA (Holotype, PP56562, Puddledock sample 185). a, b) Volume renderings showing surface of abraded fruit with four ovules/seeds in apical (a) and lateral (b) view; note irregularly arranged exotesta cells that give rise to a faintly undulate surface pattern. c, d) Transverse orthoslices through fruit and seeds from close to the base (c; orthoslice xy0852) and from the middle of the fruit (d; orthoslice xy0615) showing four ovules/seeds of which two are fully developed $(1,2)$ and two are aborted or underdeveloped $(3,4)$; outer integument composed of an outer layer of non-lignified cells (exotesta, oi-ex) and an inner layer (endotesta, oi-en) of crystal cells with endoreticulate infillings; inner integument composed of an outer layer (exotegmen, ii-ex) of smaller cells and inner layer of larger cells (meso- and endotegmen, ii-en); note that the mesoand endotegmen is well-preserved in the underdeveloped seeds, but crushed in the fully developed seeds. e) Transverse orthoslice (xy0997) through the basal part of a seed showing cells of exotesta (oi-ex), endotesta (oi-en), exotegmen (ii-ex) and partly preserved embryo (arrow). Scale bars $=500 \mu \mathrm{m}(\mathrm{a}-\mathrm{d}) ; 250 \mu \mathrm{m}(\mathrm{e})$. 

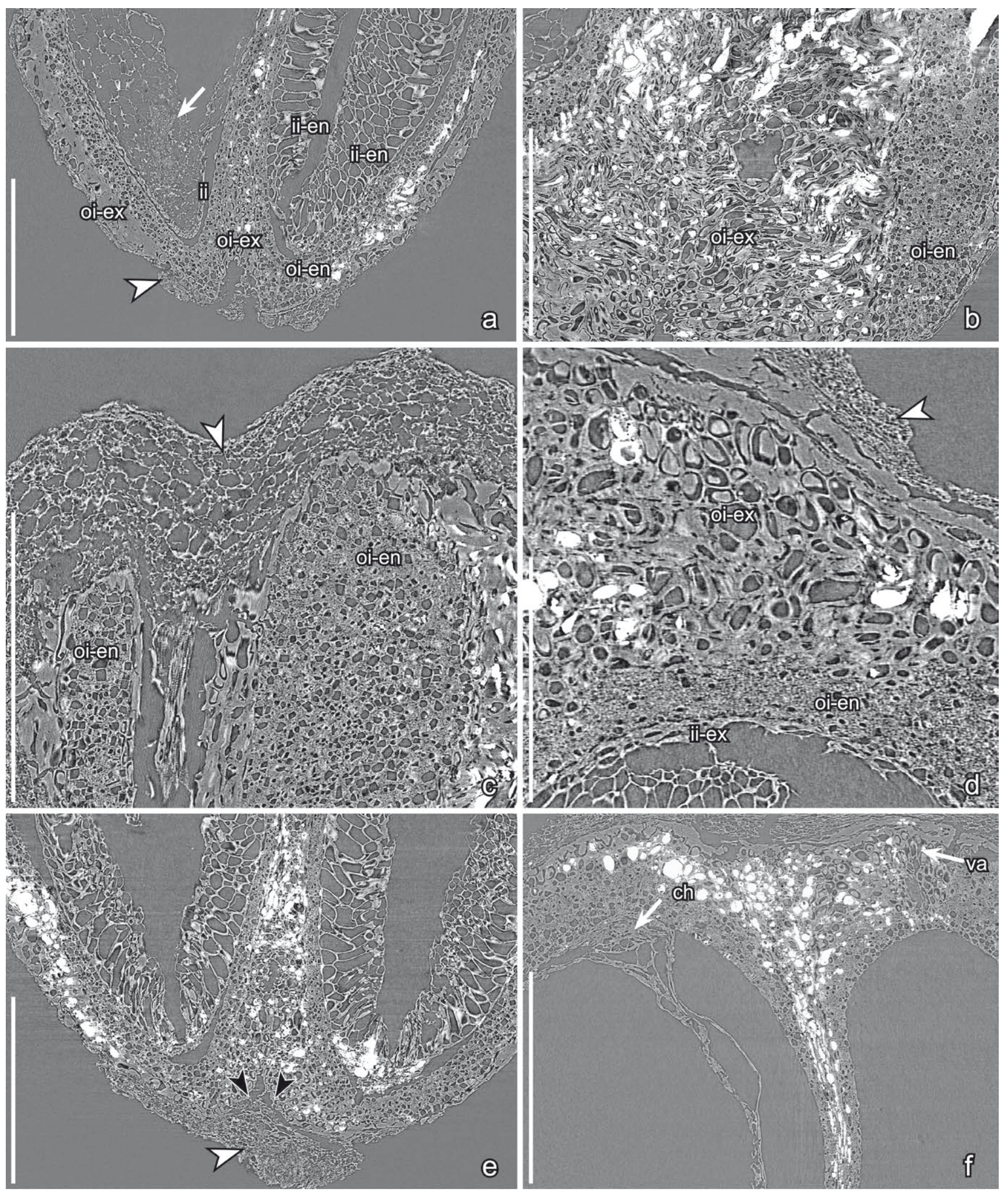

\section{Systematic palaeobotany}

Subdivisio Angiospermae LindLey, 1830

Family Chloranthaceae R.BR. ex SIMS, 1821

Genus Rightcania E.M.Fris, P.R.Crane et K.R.PEDERSEN gen. nov.

Ty p e . Designated here, Rightcania kvacekii E.M.FriIs, P.R.Crane et K.R.Pedersen gen. et sp. nov.
Plant Fossil Names Registry Number. PFN000104 (for new genus).

E ty m o log y. Rightcania is an anagram of Canrightia to indicate similarity to this fossil genus.

Diagnosis. Fruit a berry with three to five ovules/ seeds and a fruit wall of thin-walled parenchyma cells. Stigmatic area sessile, indistinct. Hypanthium fused to lower part of ovary wall. Ovules pendent, orthotropous 
to semi-orthotropous, bitegmic, endotestal with a testa of multiple cell layers. Exotesta of several layers of slightly elongate, irregular wavy cells; endotesta a single layer of cubic to palisade-shaped cells containing densely spaced crystals and fibrous infillings. Outer surface of endotesta smooth. Tegmen several cell layers thick; exotegmen of elongated fibrous cells, mesotegmen and endotegmen with large, slightly elongate and thin-walled cells; inner layers of tegmen crushed in mature seeds. Embryo tiny; nutritive tissue of isodiametric thin-walled cells.

Comments on the genus. The fruit wall of Rightcania is abraded, but remains of the hypanthium are preserved in one specimen indicating that the floral organization was semi-inferior as in the extinct chloranthoid genus Canrightia (Friis and Pedersen 2011). Other floral features are unknown, but Rightcania is also similar to Canrightia in having several orthotropous ovules/seeds enclosed in a thin-walled, probably fleshy fruit, and in having seeds with a seed coat structure closely similar to that of extant and fossil Chloranthaceae. Rightcania is very rare in the Puddledock mesofossil assemblages and include three-, four- and five-seeded fruits, whereas in the more abundant Canrightia material from Portugal the number of seeds varies between two and five (Friis and Pedersen 2011).

Prominent resin bodies in the fruit wall are characteristic for Canrightia, but have not been observed in Rightcania. Whether this reflects poor preservation of the fruit wall or original absence is unknown. Rightcania also differs from Canrightia in its thicker outer testa composed of several layers of irregular sclerenchyma cells, as well as its thicker endotesta. In both genera the inner integument (tegmen) is several cells thick with the exotegmen consisting of thickwalled cells, and the meso- and endotegmen composed of larger and thin-walled cells. The cells of the tegmen are well preserved in ovules that are not mature, but they are collapsed or consumed in mature seeds. In Canrightia the endotegmen is developed as a distinctive endothelium of radially elongated cells, while in Rightcania the endotegmen is less distinct and less clearly differentiated from mesotegmen, as is also the case in Canrightiopsis. Canrightiopsis is distinguished from Rightcania by its one-seeded fruits and thicker cell walls of the meso- and endotegmen (Friis et al. 2015).

\section{Rightcania kvacekii E.M.Fris, P.R.Crane et K.R.Pedersen sp. nov. Text-figs 1-2}

Hol otype. Designated here, PP56562 (Puddledock sample 185; illustrated here on Text-figs 1a-e, 2a-d).

Plant Fossil Names Registry Number. PFN000105 (for new species).

Paratypes designated here. PP56566 PP56568 (Puddledock sample 183); PP56564, PP56565 (Puddledock sample 185); PP56593, PP56599 (Puddledock sample 189).

R e p o s i t o r y. Palaeobotanical Collections, Department of Geology, The Field Museum, Chicago, Illinois, USA (PP).

E ty m o log y. The name kvacekii is in honor of Zlatko Kvaček for his contribution to palaeobotany.

Ty p e loc a lity. Puddledock locality, former Tarmac Lone Star Industries (Vulcan Materials Co.) sand and gravel pit, located south of Richmond and east of the Appomattox River in Prince George County, Virginia, USA ( $37^{\circ} 15^{\prime} 52^{\prime \prime}$ $\left.\mathrm{N}, 77^{\circ} 22^{\prime} 10^{\prime \prime} \mathrm{W}\right)$.

Type stratum and age. Basal part of Subzone IIB, Potomac Group; Early Cretaceous (early to middle Albian).

Di a g no sis. As for the genus.

Distinguishing features for Rightcania $k v a c e k i$. As for the genus.

D i m e n s i o n s . Length of fruit: 1.6-2.9 mm; width of fruit: $1.1-2.18 \mathrm{~mm}$.

Description and remarks. Rightcania is based on about 40 dispersed fruits and seed fragments, all preserved as lignite. The fruits are mostly three- or fourseeded, rarely five-seeded. The fruits are abraded, and one four-seeded fruit has remains of a hypanthium fused to the fruit wall. There is no other information on the attachment or organization of the flower.

The fruits are obovate in lateral view, almost circular in transverse section (Text-fig. 1a-d), about 1.6-2.9 mm long and 1.1-2.18 $\mathrm{mm}$ in diameter, with three to five ovules/

Text-fig. 2. Synchrotron radiation X-ray tomographic microscopy (SRXTM) images of Rightcania kvacekii gen. et sp. nov. from the Early Cretaceous Puddledock locality, Virginia, USA (Holotype, PP56562, Puddledock sample 185). a) Longitudinal orthoslice (yz0964) through the median plane of the fruit showing the basal parts of two seeds/ovules; seed to the left fully developed with remains of embryo (arrow) surrounded by cells of the nutritive tissue, seed to the right aborted or underdeveloped with well preserved meso- and endotegmen; seed coats showing exotesta (oi-ex), which is well-developed between the seeds, endotesta (oi-en), prominent cells of the meso- and endotegmen (ii-en) in the aborted or underdeveloped seed, and scattered remains of fruit wall (arrow head). b) Longitudinal and tangential orthoslice (xz1394) through the outer integument showing undulating pattern in the irregular cells of exotesta (oi-ex) and the crystalliferous endotesta (oi-en). c) Longitudinal orthoslice (xz0302) through apical part of the fruit showing thin-walled cells of fruit wall (arrow head) with remains of vascular bundle and sections through crystalliferous endotesta (oi-en). d) Longitudinal orthoslice (yz2351) through apical part of the fruit showing remains of fruit wall (arrow head), well-developed exotesta (oi-ex), endotesta (oi-en) and remains of the tegmen (ii-ex). e) Longitudinal orthoslice (xz1906) through the median plane of the fruit (perpendicular to orthoslice yz0964 in (2a)) showing the basal parts of two aborted or underdeveloped ovules/seeds with well-preserved meso- and endotegmen; note the clear delimitation between outer surface of exotesta of the neighboring two ovules/seeds (black arrow heads) and fruit wall (white arrow head). f) Longitudinal orthoslice (xz1190) through median plane of the fruit and the apical parts of two ovules/seeds, one showing the chalaza (ch), the other showing vascular bundle (va) entering the ovule/seed, and both indicating apical placentation. Scale bars $=\mathbf{5 0 0} \mu \mathrm{m}(\mathrm{a}-\mathrm{c}, \mathrm{e}, \mathrm{f}) ; 250 \mu \mathrm{m}(\mathrm{d})$. 

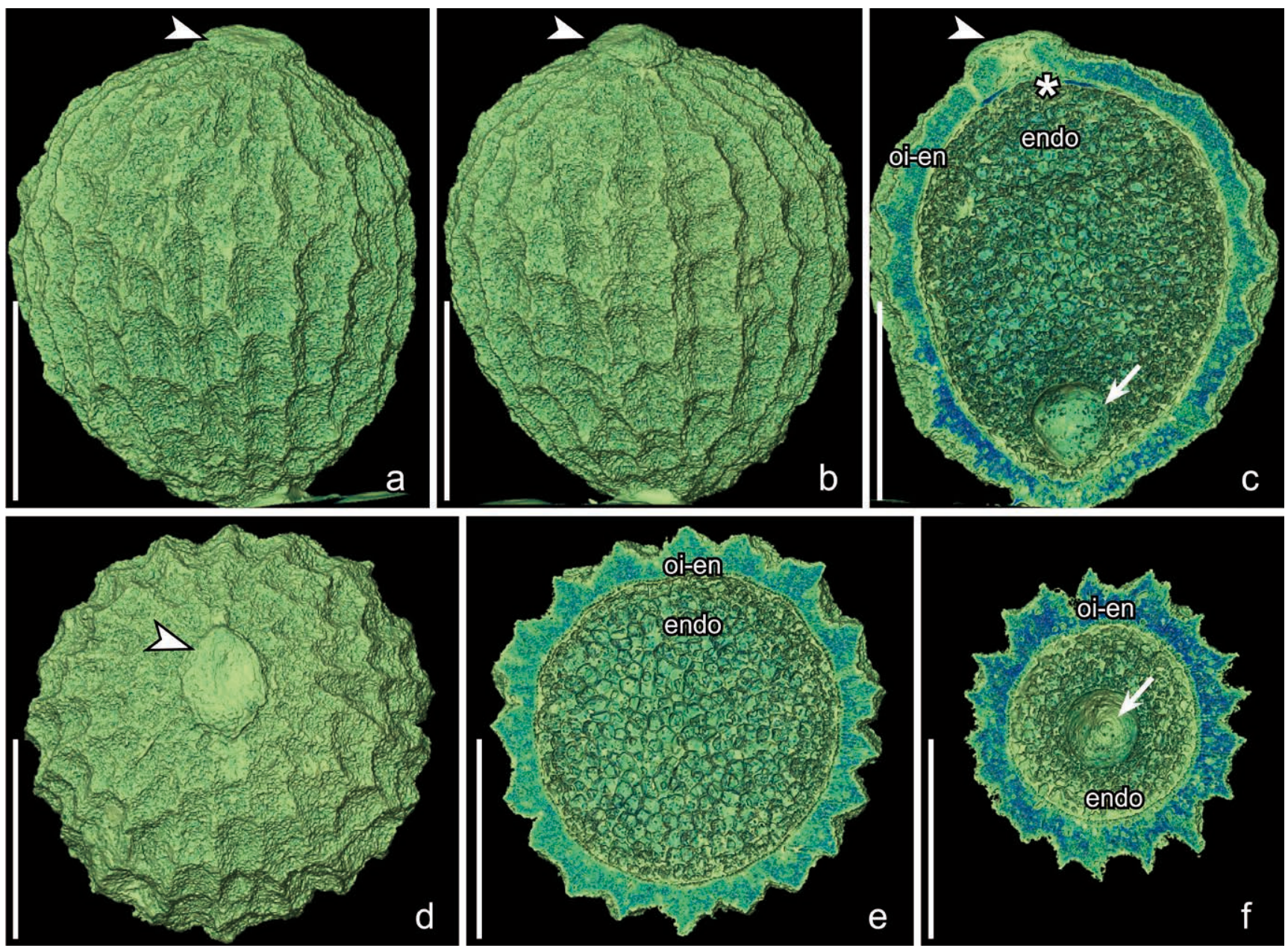

Text-fig. 3. Synchrotron radiation X-ray tomographic microscopy (SRXTM) images of Kvacekispermum rugosum gen. et sp. nov. from the Early Cretaceous Vale de Água locality, Portugal (Holotype, S174951, Vale de Água sample 141). a, b, d) Volume renderings of seed in lateral $(a, b)$ and apical $(d)$ views showing the coarsely rugulate to reticulate surface of the endotesta with the depressions arranged in poorly defined grooves and remains of the sessile, slightly raised stigma (arrow head). c) Volume rendering of specimen cut longitudinally through the median plane (cut at orthoslice yz0805) showing apical stigmatic area (arrow head), chalaza (asterisk) and endotesta (oi-en) surrounding the endosperm (endo) and embryo cavity (arrow). e, f) Volume renderings of specimen cut transversely close to the middle of the seed (e, cut at orthoslice xy0922) and near the base (f, cut at orthoslice xy1466) showing endostesta (oi-en) surrounding endosperm (endo) and embryo cavity (arrow). Scale bars $=500 \mu \mathrm{m}(\mathrm{a}-\mathrm{f})$.

seeds. The fruit wall is preserved near the fruit apex and also in small, scattered regions over the seed surface, but it is generally abraded (Text-fig. 2a, c-e). It is composed of thin-walled, more or less isodiametric, parenchyma cells. Cavities that may indicate the former presence of ethereal oil cells are occasionally present in the ground tissue of the fruit wall, but unequivocal resin bodies that would provide more definitive evidence have not been observed.

Well-preserved internal details revealed by synchrotron radiation X-ray microtomographic microscopy (SRXMT) of a larger, four-seeded specimen (Holotype, PP 56562), show that this fruit was mature or close to maturity with two fully developed seeds and two underdeveloped or aborted ovules/seeds (Text-figs 1c-e, 2a). The fruit is unilocular and the seeds are radially arranged, perhaps indicating that the gynoecium is syncarpous and evolved from three to five carpels each with a single seed.

The ovules/seeds are attached apically (Text-fig. 2f) and are slightly shorter than the fruit. The ovules/seeds are elliptical to obconical in lateral view; rounded at the chalazal end (apical) and slightly pointed at the micropylar end (basal). The seeds are triangular to almost circular in transverse section with flattened or concave contact faces (Text-fig. 1a, c, d). The stigma is poorly preserved, but was apparently sessile.

The ovules/seeds are orthotropous to hemi-orthotropous, bitegmic and endotestal. The outer integument is composed of an exotesta and endotesta. The exotesta is composed of elongated sclerenchyma cells, several cell layers deep arranged longitudinally in an irregularly wavy pattern (Text-figs $1 \mathrm{~b}$, $2 b)$. The separation between the exotesta of adjacent seeds is often not distinct, which can give the fruit the appearance of being septate. However, the separation is clear close to the fruit wall (Text-fig. 2e). The exotesta is up to $120 \mu \mathrm{m}$ thick adjacent to the carpel wall and $70 \mu \mathrm{m}$ thick between the seeds.

The endotesta has a smooth outer surface and is composed of cubic to palisade-shaped crystal cells, one cell layer deep. The cells have densely packed crystals internally that are seen as cubic imprints in the cell lumen, which is otherwise filled by an endoreticulate infilling of fibres (Textfigs $1 \mathrm{c}-\mathrm{e}, 2 \mathrm{a}, \mathrm{c})$. The endotesta is about $60 \mu \mathrm{m}$ thick adjacent 

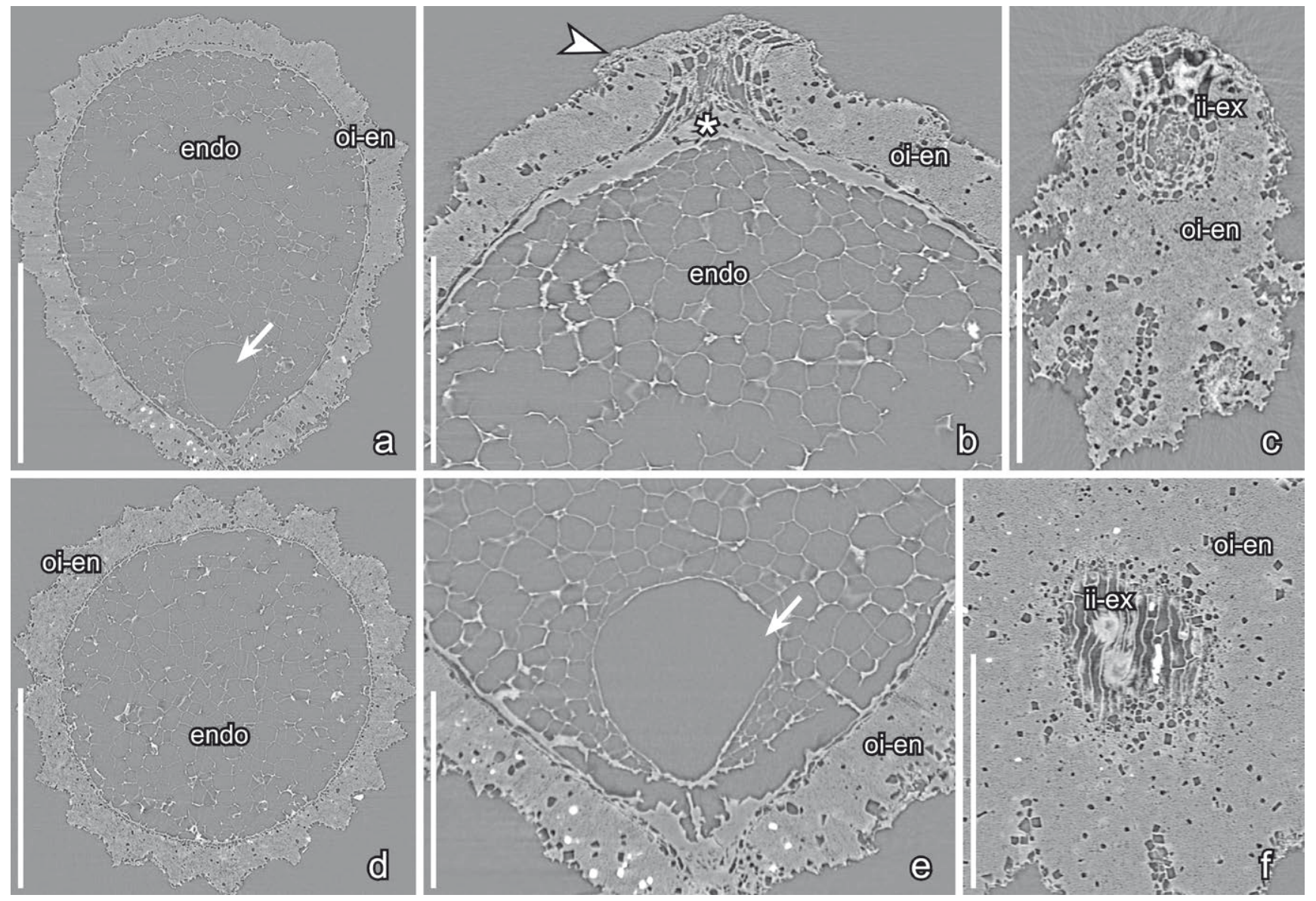

Text-fig. 4. Synchrotron radiation X-ray tomographic microscopy (SRXTM) images of Kvacekispermum rugusum gen. et sp. nov. from the Early Cretaceous Vale de Água locality, Portugal (Holotype, S174951, Vale de Água sample 141). a-f) Longitudinal (a, b, c, e, f) and transverse (d) orthoslices through seed showing slightly raised stigma (arrow head) chalaza (asterisk) and endotesta (oi-en) surrounding endosperm with embryo cavity (arrow); details of endotesta (c, f) show clusters of crystals in grooves of the endotesta (oi-en) and cells of exotegmen (ii-ex). Scale bars = 500 $\mu \mathrm{m}$ (a, d); $200 \mu \mathrm{m}(\mathrm{b}, \mathrm{e}) ; 250 \mu \mathrm{m}$ (f); $100 \mu \mathrm{m}$ (c).

to the carpel wall and about $30 \mu \mathrm{m}$ thick along the contact faces between the seeds.

In the holotype analysed using SRXTM the cells of the tegmen are mostly crushed in the fully developed seeds (Text-figs 1c-e, 2a), whereas in the two ovules/seeds that are thought to be underdeveloped or aborted (Text-figs 1c, d, $2 \mathrm{a})$, the tegmen is better preserved. In the fully developed, and also in the underdeveloped or aborted ovules/seeds the exotegmen consists of narrow, thick-walled cells. Mesoand endotegmen are only well preserved in the aborted or undeveloped ovules/seeds, where they consist of several layers of larger, thin-walled cells. The tegmen probably served as a nutritive tissue for the developing embryo and was consumed in the two fully mature seeds.

A tiny embryo is partly preserved in one of the fully developed seeds (Text-figs 1c, e, 2a). It is positioned close to the micropyle and is formed of minute, almost isodiametric cells. The embryo is surrounded by larger, thin-walled cells that comprise the remains of the nutritive tissue and are interpreted as cells of the endosperm (Text-fig. 2a).

\section{Kvacekispermum E.M.Fris, P.R.Crane et K.R.PEdersen} gen. nov.

Type. Designated here, Kvacekispermum rugosum E.M.Fris, P.R.Crane et K.R. Pedersen gen. et sp. nov.
Plant Fossil Names Registry Number. PFN000106 (for new genus).

Etymology. The name Kvacekispermum is in honor of Zlatko Kvaček for his numerous contributions to palaeobotany.

D i a g n o s i s. Seeds broadly obovate in lateral view and almost circular in transverse section with coarsely rugulate to reticulate surface formed from the uneven outer surface of endotesta in which the depressions are arranged in poorly defined grooves. Stigmatic area sessile on the fruit apex, slightly raised, hemispherical. Ovule pendent, orthotropous, bitegmic, endotestal. Endotesta comprised of a single layer of palisade-shaped cells with densely spaced crystals and fibrous infillings. Tegmen crushed in mature seeds. Embryo tiny; nutritive tissue of isodiametric thin-walled cells.

Comments on the genus. The fruit wall of Kvacekispermum is abraded except in the region of the stigma. There is no indication of floral organization or pollen, and detailed comparison with the floral organization in Canrightia and Canrightiopsis is not possible. However, Kvacekispermum is similar to Canrightiopsis in having a pendent, orthotropous and bitegmic ovule/seed with a thick endotestal seed coat. The shape of the seed, together 

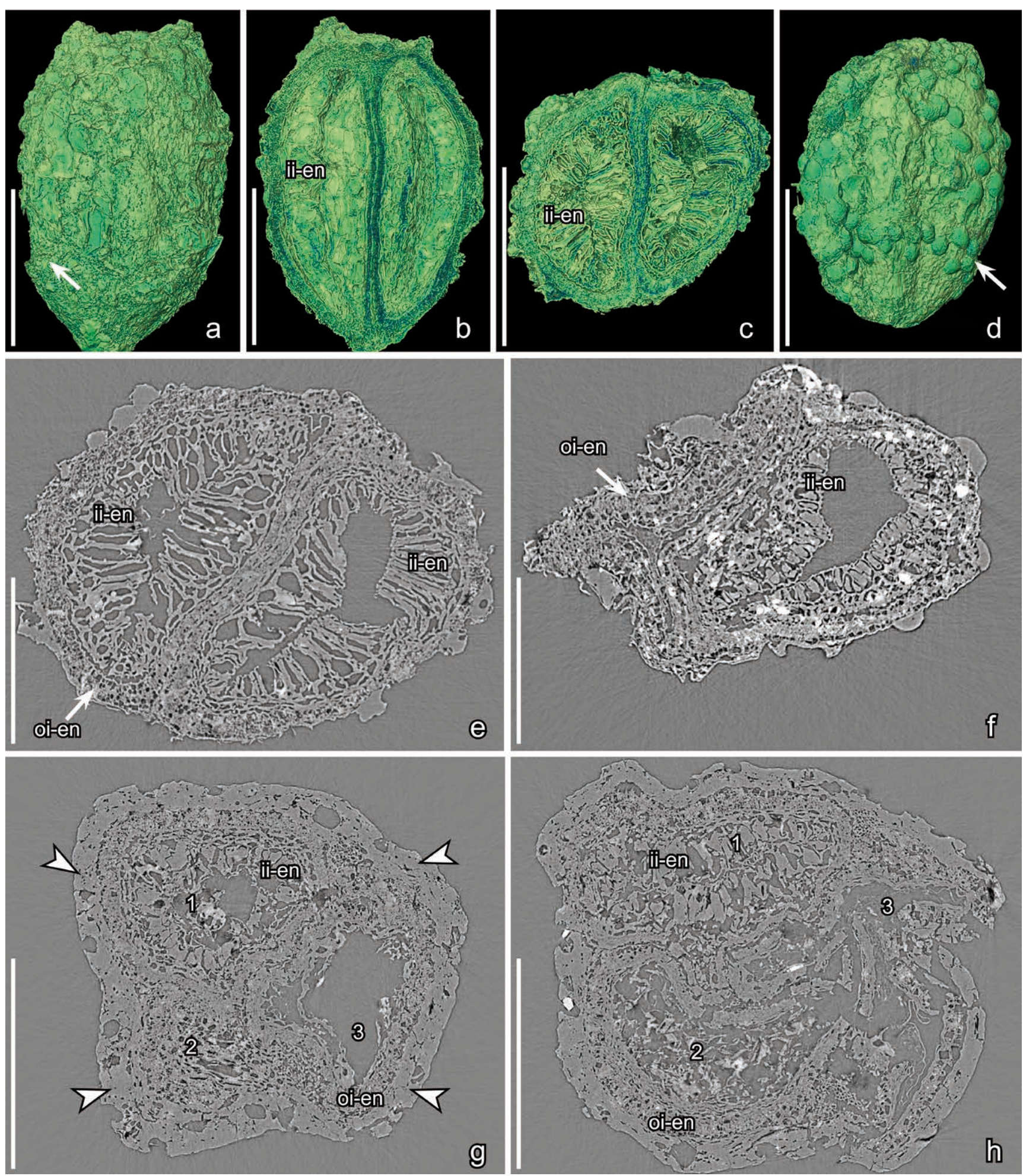

with the central position of the stigma, also indicate that Kvacekispermum had single-seeded fruits similar to Canrightiopsis. Both also have a tiny embryo surrounded by a nutritive tissue of small, equiaxial cells with thin cell walls. Kvacekispermum is distinguished from seeds of Canrightiopsis by the coarsely rugulate surface of the endotesta, which contrasts with the foveolate endotesta surface characteristic of all species of Canrightiopsis.

The fossil fruits and seeds of Kvacekispermum and Canrightiopsis share many features with fruits and seeds of extant Ascarina, Sarcandra and Chloranthus, but
Canrightiopsis is distinguished from the extant taxa by features of its androecium. Floral organisation is not known for Kvacekispermum, but the seed is distinguished from seeds of extant taxa by its thicker seed coat and the coarsely rugulate surface of the endotesta.

\section{Kvacekispermum rugosum E.M.FrIIS, P.R.CRANE et K.R.Pedersen sp. nov.}

Text-figs 3, 4

H o lo ty p e. Designated here, S174951 (Vale de Água 141; illustrated here on Text-figs 3a-f, 4a-f). 
Plant Fossil Names Registry Number. PFN000107 (for new species).

R e p o s i t o r y. Palaeobotanical Collections, Department of Palaeobiology, Swedish Museum of Natural History (S).

Etymology. The specific epithet is from Latin rugosus: wrinkled.

Type locality. Vale de Água locality, Portugal $\left(39^{\circ} 37^{\prime} 15^{\prime \prime} \mathrm{N}, 08^{\circ} 51^{\prime} 30^{\prime \prime} \mathrm{W}\right)$.

Type horizon and age. Early Cretaceous (late Aptian - early Albian; basal part of the Figueira da Foz Formation).

D i a g nos is. As for the genus.

Distinguishing features for Kvacekispermum rugosum. As for the genus.

D imensions. Length of seed: $1.14 \mathrm{~mm}$; width of seed: $1.04 \mathrm{~mm}$.

Description and remarks. Kvacekispermum rugosum is known from a single well-preserved seed. The seed is abraded, and the fruit wall is missing except near the apex where stigma is preserved. There is no information on organization of the flower, but synchrotron radiation X-ray microtomographic microscopy (SRXMT) of the seed (Holotype, S174951) has revealed fine details of the endotesta and nutritive tissue.

The seed is broadly obovate in lateral view, almost circular in transverse section, about $1.14 \mathrm{~mm}$ long and 1.04 $\mathrm{mm}$ in diameter, with rounded (apical) chalazal region and slightly pointed (basal) micropylar region (Text-figs $3 \mathrm{a}-\mathrm{f}$, $4 \mathrm{a}-\mathrm{e})$. The stigma, at the seed apex is sessile, slightly raised and hemispherical (Text-fig. 3a-d). The position of the stigma and the shape of the seed, as well as comparison to fruits and seeds of Canrightiopsis, suggest that the fruits of Kvacekispermum were one-seeded.

The seed is orthotropous and pendent, bitegmic and endotestal. The seed surface is coarsely rugulate to reticulate due to differences in the size of the cells comprising the endotesta with the resulting depressions arranged in poorly defined grooves. The endotesta is $60-125 \mu \mathrm{m}$ thick consisting of a single layer of palisade-shaped crystal cells with endoreticulate infillings of fibres and imprints of small cubic crystals (Text-figs 3c-e, 4a, c). The crystals appear to be more densely packed close to the outer surface of the irregular grooves in the coarsely rugulate to reticulate surface (Text-fig. 4c, d). The exotesta consists of small, thinwalled cells that are preserved only in small patches in the grooves of the endotesta. The tegmen is collapsed in the mature seed, but the narrow, longitudinally arranged cells of the exotegmen are well preserved (Text-fig. $4 \mathrm{a}-\mathrm{d}, \mathrm{f}$ ).

The embryo is not preserved, but there is a very small well-defined embryo cavity (Text-figs 3c, f, 4a, e) indicating that the embryo was tiny. The surrounding nutritive tissue consists of thin-walled cells that do not show signs of shrinkage (Text-fig. 4a, b, d, e). Based on comparison with extant angiosperms the nutritive tissue is interpreted as endosperm.

\section{Discussion}

\section{Comparision of Rightcania kvacekii and Kvacekisper- mum rugosum with other fossils}

Rightcania kvacekii and Kvacekispermum rugosum are characterized by their pendent, orthotropous, bitegmic and endotestal ovules/seeds, in which the endotesta is composed of one layer of crystalliferous cells infilled with fibrous endoreticulum. Among extant angiosperms this combination of features is known only in the ovules/seeds of Ascarina, Chloranthus and Sarcandra (Chloranthaceae). Similar seeds are also characteristic of the extinct chloranthoid taxa Canrightia and Canrightiopsis from the Early Cretaceous of Portugal (Friis and Pedersen 2011, Friis et al. 2015), for fossil seeds associated with Chloranthistemon P.R.CRANE, E.M.FriIs et K.R.PEDERSEN from the Late Cretaceous mesofossil floras of Åsen, Sweden, and for undescribed fossil seeds from Martha's Vineyard, Massachusetts, USA (Friis, Crane and Pedersen, work in progress). Zlatkocarpus J.KvaČEK et E.M.FriIs from the early Cenomanian of the Czech Republic, is a further potentially related chloranthoid taxon with one-seeded fruits, but unfortunately details of the seed coat are unknown (Kvaček and Friis 2010).

The extinct genus Rightcania is especially similar to the extinct genus Canrightia. Both have fruits with a thin, probably fleshy, fruit wall and three to five (Rightcania) or two to five (Canrightia) seeds. It is also interesting that the

Text-fig. 5. Synchrotron radiation X-ray tomographic microscopy (SRXTM) images of Canrightia resinifera from the Early Cretaceous Famalicão locality (a-f; Famalicão sample 25), Portugal, and Canrightia sp. from the Early Cretaceous Torres Vedras locality (g, h; Torres Vedras sample 38). a) Volume rendering of fruit with two seeds showing surface of fruit with hypanthium (arrow at hypanthium rim) and resin bodies in fruit wall (S174952). b, c) Volume renderings of the same specimen shown in Figure 5 a cut longitudinally in the median plane (b, cut at orthoslice xz0462) and transversely through the middle of the specimen (c, cut at orthoslice xy0706) showing the pronounced radially elongated cells of endotegmen (endothelium, ii-en). d) Volume rendering of fruit with two seeds showing hypanthium (arrow at hypanthium rim) and densely spaced resin bodies in the fruit wall (S171512). e) Transverse orthoslice (xy0700) through middle of fruit in Figure 5a showing two underdeveloped ovules/seeds with a thin crystalliferous endotesta (oi-en) and a pronounced endothelium formed from the inner layer of tegmen (ii-en). f) Transverse orthoslice (xy0384) through middle of fruit in Figure 5d showing one underdeveloped ovule/seed and one mature (crushed) seed; crystalliferous endotesta (oi-en) thin; inner integument with smaller cells of endotegmen (ii-en) in the underdeveloped ovule/seed may suggest that the tegmen is partly consumed. $\mathrm{g}, \mathrm{h}$ ) Transverse orthoslices of fruit with three ovules/seeds close to the fruit apex (g, orthoslice xy0670) and slightly further down in the fruit (xy1075) showing the wall (arrow heads) of the single fruit enclosing three ovules/seeds (1-3); one ovule/seed (1) is underdeveloped with clear preservation of the endotegmen (ii-en) while the other two $(2,3)$ are fully developed and the endotegmen is not visible; the endotesta (oi-en) in both underdeveloped and developed ovules/ seeds is of the same thickness (S174100). Scale bars $=500 \mu \mathrm{m}(\mathrm{a}-\mathrm{d}) ; 250 \mu \mathrm{m}(\mathrm{e}-\mathrm{h})$. 

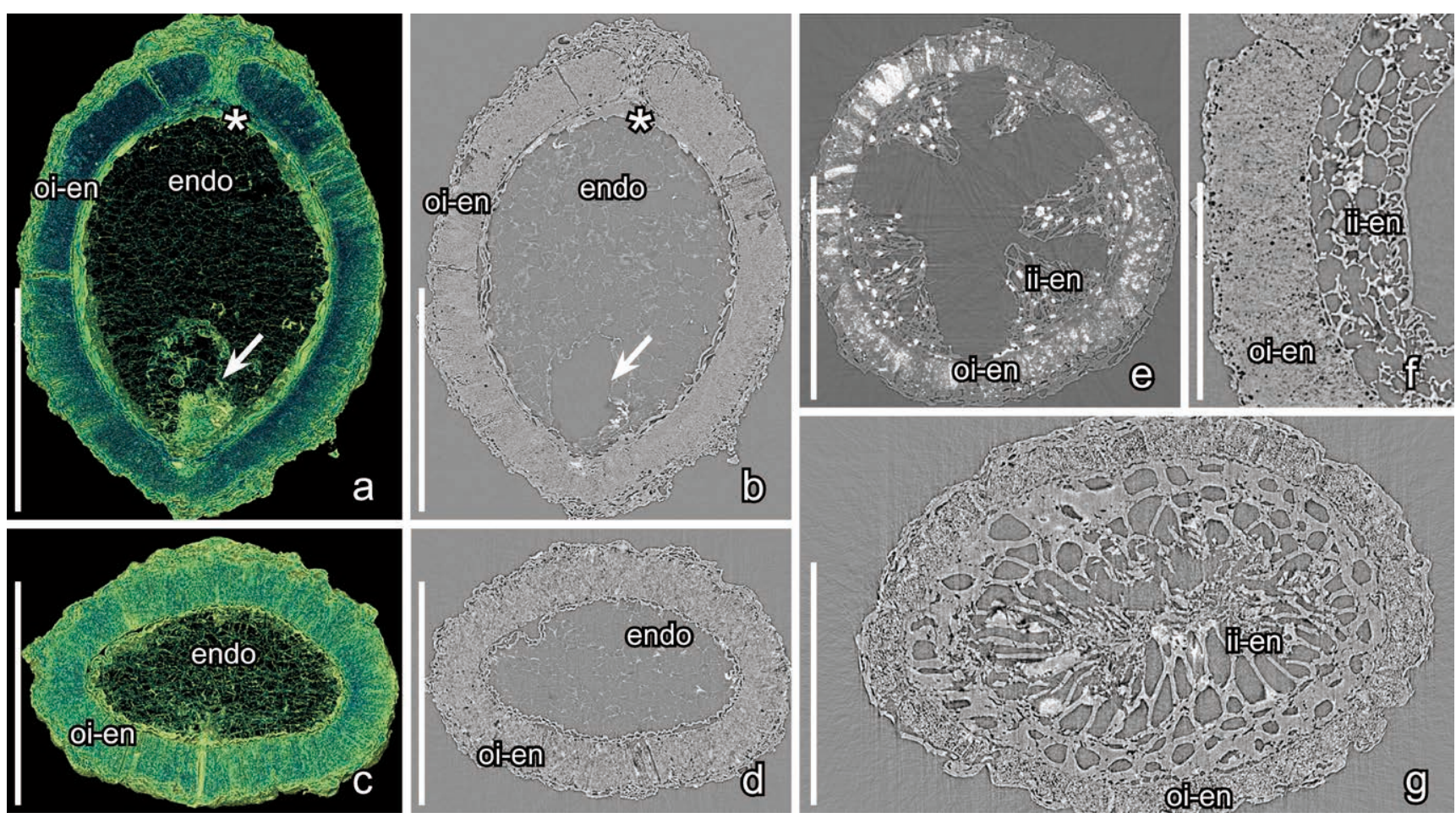

Text-fig. 6. Synchrotron radiation X-ray tomographic microscopy (SRXTM) images of Canrightiopsis from the Early Cretaceous of Portugal. a-d) Volume renderings (a, c) and orthoslices $(b, d)$ of fruit of Canrightiopsis crassitesta from the Catefica locality (S174159; Catefica sample 49) in longitudinal (a, cut between orthoslice yz0440-510; b, orthoslice xz0511) and transverse sections (c, cut between orthoslices xy0800-0900; d, orthoslice xy0949) showing thick crystalliferous endotesta (oi-en), chalaza (asterisk) and endosperm (endo) with embryo cavity (arrow). e) Transverse orthoslice of fruit of Canrightiopsis intermedia from the Famalicão locality (S174004; Famalicão sample 25) showing endotesta (oi-en) and remains of tegmen with large cells of meso- and endotegmen (ii-en). f) Transverse orthoslice of fruit of Canrightiopsis sp. from the Catefica locality (S174039; Catefica sample 49) with thick endotesta (oi-en) and tegmen consisting of several layers of thin-walled cells (ii-en). g) Transverse orthoslice of fruit of Canrightia sp. from the Famalicão locality (S174149; Famalicão sample 25) with an underdeveloped seed; note thick crystalliferous endotesta (oi-en) and thick-walled cells of meso- and endotegmen (ii-en). Scale bars = 500 $\mu \mathrm{m}$ (a-e); $250 \mu \mathrm{m}$ (f, g).

fruits of Canrightia commonly include underdeveloped or aborted ovules/seeds together with fully developed seeds (Text-fig. $5 \mathrm{f}-\mathrm{h}$ ), as is also seen in Rightcania. In some cases all the seeds appear undeveloped or aborted (Text-fig. 5c, e).

Fruits and seeds of Canrightia are extremely common in Early Cretaceous mesofossil floras from Portugal. The number of seeds per fruit varies from two in almost all specimens from the Famalicão mesofossil flora (Text-fig. $5 \mathrm{~b}, \mathrm{c}, \mathrm{e}, \mathrm{f}$ ), to three to five in specimens from the mesofossil floras of Arazede, Buarcos, Catefica, Vale de Agua and Vila Verde 2. All specimens from these localities are encompassed in a single species, Canrightia resinifera E.M.FrIIs et K.R.Pedersen (Friis and Pedersen 2011), although further refinement of species limits may be possible as additional specimens are discovered. A further species of Canrightia with three ovules/seeds (Text-fig. $5 \mathrm{~g}, \mathrm{~h}$ ) has recently been discovered from the Torres Vedras mesofossil assemblage (Friis, Crane and Pedersen, work in progress).

Most specimens of Canrightia resinifera have densely spaced resin bodies in the fruit wall that are thought to represent fossilized ethereal oil cells (Text-fig. 5a-f), but the occurrence of resin bodies is most pronounced in charcoalified specimens from the Famalicão locality. Resin bodies are not as obvious in lignified specimens, for example from the type locality at Catefica. In specimens of Rightcania the fruit wall is generally abraded and there are no traces of resin bodies.
It is uncertain whether this is because of abrasion or because they were not present in the original fruit wall.

Rightcania is known from about 40 specimens in the Puddledock flora, mostly with three and four seeds, rarely with five seeds. The number of seeds falls within the range of Canrightia although a larger sample may have documented a greater range. The main differences between the two genera are the much thicker seed coat in Rightcania, and nature of exotesta and tegmen (compare Text-figs 1-2 with Text-fig. 5). In Rightcania the endotesta is 30-60 $\mu \mathrm{m}$ thick while in Canrightia the thickness is $20 \mu \mathrm{m}$. In Rightcania the exotesta is also much thicker and very pronounced between the seeds, whereas in Canrightia it is thin and only seen as a very thin zone between the seeds (Text-fig. 5e, f). The most marked difference between the two genera is the nature of the tegmen. In underdeveloped or aborted ovules/ seeds of Canrightia there is a distinct and evenly developed endothelium of radially elongate cells internal to the smaller cells of exo- and mesotegmen (Text-fig. 5c, e, f), whereas in Rightcania the tegmen is less evenly developed and the cells of the meso- and endotegmen are of more or less similar size (Text-figs 1c, d, 2a). Rightcania is more like Canrightiopsis than Canrightia in features of the tegmen. In Canrightiopsis underdeveloped or aborted ovules/seeds the meso- and endotesta cells are of more or less equal size (Text-fig. 6e-g) and the tegmen is often fragmented, 
perhaps partly reflecting consumption of the tegmen cells by the developing embryo.

Flowers of Canrightia were bisexual and perigynous, characterized by a short hypanthium fused to the ovary wall. The floral organization is not always clear, but there are specimens that clearly show the tips of tiny tepals on the rim of the hypanthium in a radially symmetrical arrangement. Each tepal has a stamen (stamen scar) that is opposite the tepal, not alternating as in the floral diagram of Doyle and Endress (2014). The fruit wall that encloses all the seeds (Text-fig. 5g, h) shows that the gynoecium of Canrightia develops into a single fruit and was not apocarpous as indicated by Doyle and Endress (2014). The fruit wall is abraded in Rightcania, but remains of the hypanthium are preserved in one specimen: this indicates a floral organization similar to that of Canrightia with semiinferior ovary and hypanthium fused to the ovary wall. Also the apical and radial arrangement of ovules/seeds indicates that the gynoecium of Rightcania was syncarpous formed from three to five carpels. Although a possible scar is preserved at the top of the hypanthium it is not clear whether the flowers of Rightcania were bisexual. This, together with the differences in details of the seed coat, warrant the establishment of a new genus.

The seed of Kvacekispermum rugosum is closely similar to seeds of the extinct genus Canrightiopsis. In addition to similarities in seed coat and ovule/seed organization the two taxa are also very similar in the size of the embryo and cellular details of the endosperm (compare Text-figs 3, 4 with Text-fig. 6). Kvacekispermum differs, however, in the coarsely rugulate surface of the endotesta.

Canrightiopsis occurs abundantly among Early Cretaceous mesofossils from Portugal and includes three species, C. intermedia E.M.Fris, G.W.Grimm, M.M.Mendes et K.R. Pedersen, C. crassitesta E.M.Fris, G.W.Grimm, M.M.Mendes et K.R.Pedersen and $C$. dinisii E.M.FriIs, G.W.Grimm, M.M.Mendes et K.R.Pedersen, as well as several taxa referred to as Canrightiopsis sp. (Friis et al. 2015). All seeds of Canrightiopsis have distinctly foveolate surface to the endotesta with small cavities in longitudinal furrows, which contrasts with the coarsely rugulate to reticulate surface of Kvacekispermum. Canrightiopsis also includes several well-preserved specimens in which the fruit wall is preserved and shows the scars of the stamens, conclusively demonstrating that the fruit was unilocular, oneseeded and with a dorsally displaced androecium of three separate stamens. In the single seed of Kvacekispermum only small patches of the tissues outside the endotesta (exotesta and fruit wall) are present and the poor preservation does not allow inferences about the androecium and hypanthium. The position of the stigma on top of the seed, together with the rounded transverse section of the seed, indicate that as in Canrightiopsis the seed was produced in a unilocular and one-seeded fruit.

\section{Conclusion}

The orthotropous organization of Rightcania and Kvacekispermum seeds, coupled with the characteristic structure of the endotesta, which is composed of a single layer of crystalliferous cells with endoreticulate infillings, place the fossils among chloranthaceous angiosperms. These two new genera therefore further expand the extinct diversity of chloranthoid angiosperms known before the end of the Early Cretaceous. Rightcania also provides the first evidence of the Canrightia-Canrightiopsis complex outside of the Portuguese mesofossil floras, indicating that this group of extinct genera, which are closely related to Ascarina, Chloranthus and Sarcandra, were also widespread in parallel to the broad distribution of early Hedyosum-like forms.

Rightcania is also significant in demonstrating that extinct early chloranthoids with more than one seed were common among Early Cretaceous members of the group. This feature is not seen among the four extant genera of Chloranthaceae, which highlights the limitations of inferring detailed patterns of character evolution based on data from extant taxa alone. Together with abundant evidence of many other extinct taxa at this level of angiosperm evolution (Friis et al. 2018a, b) the potential impacts of extinct chloranthoid diversity on phylogenetic relationships at the base of the angiosperm tree could also be profound.

\section{Acknowledgements}

The Paul Scherrer Institute, Villigen, Switzerland is thanked for provision of synchrotron radiation beamtime at the TOMCAT beamline X02DA of the Swiss Light Source (projects 20110963, 20130185, 20141047, 20160140 and 20171476) and the Swedish Research Council (2014-5228 to E. M. Friis) for financial support. We also thank Federica Marone for her help at the beamline, Anna Lindström for help with the SRXTM analyses, and Steve Manchester and Patrick Herendeen for helpful comments on the manuscript.

\section{References}

Archangelsky, S., Taylor, T. N. (1993): The ultrastructure of in situ Clavatipollenites pollen from the Early Cretaceous of Patagonia. - American Journal of Botany 80: 879-885. https://doi.org/10.1002/j.1537-2197.1993.tb15308.x

Couper, R. A. (1960): New Zealand Mesozoic and Cainozoic plant microfossils. - Palaeontological Bulletin, New Zealand Geological Survey, 32: 1-87.

Crane, P. R., Friis, E. M., Pedersen, K. R. (1989): Reproductive structure and function in Cretaceous Chloranthaceae. Plant Systematics and Evolution, 165: 211-226. https://doi.org/10.1007/BF00936003

Crane, P. R., Friis, E. M., Pedersen, K. R. (1994): Paleobotanical evidence on the early radiation of magnoliid angiosperms. - Plant Systematics and Evolution, Supplement 8: 51-72.

Doyle, J. A., Endress, P. K. (2014): Integrating Early Cretaceous fossils into the phylogeny of living angiosperms: ANITA lines and relatives of Chloranthaceae. International Journal of Plant Sciences, 175: 555-600. https://doi.org/10.1086/675935

Eklund, H., Friis, E. M., Pedersen, K. R. (1997): Chloranthaceous floral structures from the Late 
Cretaceous of Sweden. - Plant Systematics and Evolution 207: $13-42$.

https://doi.org/10.1007/BF00985207

Friis, E. M., Crane, P. R., Pedersen, K. R. (1997): Fossil history of magnoliid angiosperms. - In: Iwatsuki, K., Raven, P. H. (eds), Evolution and diversification of land plants. Springer-Verlag, Tokyo, Berlin, Heidelberg, New York, pp. 121-156.

https://doi.org/10.1007/978-4-431-65918-1_6

Friis, E. M., Crane, P. R., Pedersen, K. R. (2011): Early flowers and angiosperm evolution. - Cambridge University Press, Cambridge, New York, Melbourne, Madrid, Cape Town, Singapore, São Paulo, Delhi, Tokyo, Mexico City, 596 pp. https://doi.org/10.1017/CBO9780511980206

Friis, E. M., Crane, P. R., Pedersen, K. R. (2018a): Fossil seeds with affinities to Austrobaileyales and Nymphaeales from the Early Cretaceous (early to middle Albian) of Virginia and Maryland, U.S.A: new evidence for extensive extinction near the base of the angiosperm tree. - In: Krings, M., Harper, C. J., Cúneo, N. R., Rothwell, G. W. (eds), Transformative paleobotany. Academic Press, London, pp. 417-435

Friis, E. M., Crane, P. R., Pedersen, K. R. (2018b): Early angiosperm diversity: evidence of extinct taxa close to Austrobaileyales and Nymphaeales based on exotestal seeds from the Early Cretaceous of Portugal. - Fossil Imprint, 74(1-2): 135-158. https://doi.org/10.2478/if-2018-0010

Friis, E. M., Grimm, G. W., Mendes, M. M., Pedersen, K. R. (2015): Canrightiopsis, a new Early Cretaceous fossil with Clavatipollenites-type pollen bridge the gap between extinct Canrightia and extant Chloranthaceae.Grana, 54: 184-212. https://doi.org/10.1080/00173134.2015.1060750

Friis, E. M., Marone, F., Pedersen, K. R., Crane, P. R., Stampanoni, M. (2014): Three-dimensional visualization of fossil flowers, fruits, seeds and other plant remains using synchrotron radiation X-ray tomographic microscopy (SRXTM): New insights into Cretaceous plant diversity. - Journal of Paleontology, 88: 684-701. https://doi.org/10.1666/13-099

Friis, E. M., Pedersen, K. R. (2011): Canrightia resinifera gen. et sp. nov., a new extinct angiosperm with Retimonocolpites-type pollen from the Early Cretaceous of Portugal: missing link in the eumagnoliid tree? Grana, 50: 3-29. https://doi.org/10.1080/00173134.2011.559728

Friis, E. M., Pedersen, K. R., Crane, P. R. (1999): Early angiosperm diversification: the diversity of pollen associated with angiosperm reproductive structures in Early Cretaceous floras from Portugal. - Annals of the Missouri Botanical Garden, 86: 259-296. https://doi.org/10.2307/2666179

Friis, E. M., Pedersen, K. R., Crane, P. R. (2009): Early Cretaceous mesofossils from Portugal and eastern North
America related to the Bennettitales-ErdtmanithecalesGnetales group. - American Journal of Botany, 96: 252-283.

https://doi.org/10.3732/ajb.0800113

Hartkopf-Fröder, C., Rust, J., Wappler, T., Friis, E. M., Viehofen, A. (2011): Mid-Cretaceous charred fossil flowers reveal direct observation of arthropod feeding strategies. - Biological Letters, 8(2): 295-298. https://doi.org/10.1098/rsbl.2011.0696

Hedlund, R. W., Norris, G. (1968): Spores and pollen grains from Fredericksburgian (Albian) strata, Marshall County, Oklahoma. - Pollen et Spores, 10: 129-159.

Herendeen, P. S., Crepet, W. L., Nixon, K. C. (1993): Chloranthus-like stamens from the Upper Cretaceous of New Jersey. - American Journal of Botany, 80: 865-871. https://doi.org/10.1002/j.1537-2197.1993.tb15306.x

Hughes, N. F. (1994): The Enigma of Angiosperm Origins. - Cambridge University Press, Cambridge, New York, Melbourne, $317 \mathrm{pp}$.

Kvaček, J., Friis, E. M. (2010): Zlatkocarpus gen. nov., a new angiosperm reproductive structure with monocolpatereticulate pollen from the Late Cretaceous (Cenomanian) of the Czech Republic. - Grana, 49: 115-127. https://doi.org/10.1080/00173134.2010.481845

Martínez, C., Madriñán, S., Zavada, M., Alberto Jaramillo, C. (2013): Tracing the fossil pollen record of Hedyosmum (Chloranthaceae), an old lineage with recent Neotropical diversification. - Grana, 52: 161-180. https://doi.org/10.1080/00173134.2012.760646

Stampanoni, M., Groso, A., Isenegger, A., Mikuljan, G., Chen, Q., Bertrand, A., Henein, S., Betemps, R., Frommherz, U., Bohler, P., Meister, D., Lange, M., Abela, R. (2006): Trends in synchrotron-based tomographic imaging: the SLS experience. - In: Bonse, U. (ed.), Developments in X-Ray Tomography V. Proceedings of SPIE-The International Society for Optical Engineering, 6318: 14 pp. https://doi.org/10.1117/12.679497

Todzia, C. A. (1993): Chloranthaceae. - In: Kubitzki, K., Rohwer, J. G., Bittrich, V. (eds), The Families and Genera of Vascular Plants. II Flowering Plants - Dicotyledons. Magnoliid, Hamamelid and Caryophyllid Families. Springer-Verlag, Berlin, Heidelberg, New York, pp. 281-289. https://doi.org/10.1007/978-3-662-02899-5_27

Walker, J. W., Walker, A. G. (1984): Ultrastructure of Lower Cretaceous angiosperm pollen and the origin and early evolution of flowering plants. - Annals of the Missouri Botanical Garden, 71: 464-521. https://doi.org/10.2307/2399035

Zhang, L.-B., Renner, S. S. (2003): The deepest splits in Chloranthaceae as resolved by chloroplast sequences. International Journal of Plant Sciences, 164: S383-S392. https://doi.org/10.1086/376882 